\title{
Antennal sensillar equipment in closely related predatory wasp species (Hymenoptera: Philanthinae) hunting for different prey types
}

\section{Équipement sensoriel des antennes dans des espèces proches de guêpes prédateurs (Hymenoptera: Philanthinae), qui chassent des proies différentes}

\author{
Carlo Polidori ${ }^{\text {a,* }}$, Alberto Jorge García ${ }^{\mathrm{b}}$, José L. Nieves-Aldrey ${ }^{\mathrm{a}}$ \\ ${ }^{a}$ Departamento de Biodiversidad y Biología Evolutiva, Museo Nacional de Ciencias Naturales, C/José Gutiérrez Abascal 2, 28006 Madrid, Spain \\ ${ }^{\mathrm{b}}$ Laboratorio de Microscopia, Museo Nacional de Ciencias Naturales, C/José Gutiérrez Abascal 2, 28006 Madrid, Spain
}

\section{A R T I C L E I N F O}

\section{Article history:}

Received 17 November 2011

Accepted after revision 19 March 2012

Available online 24 April 2012

\section{Keywords:}

Hymenoptera

Crabronidae

Sensilla size

Comparative morphology

Prey selection

\begin{abstract}
A B S T R A C T
Despite its potential value in phylogenetic and ecological studies, the morphology of antennal sensilla has rarely been compared quantitatively within the Apoidea. Here, through a scanning electron microscopy analysis, we provide an inventory of different types of antennal sensilla and compare their morphology across 10 species of predatory wasps (Crabronidae: Philanthinae) including species that hunt exclusively either on beetles or on bees to feed their larvae. A sensilla-free area was found on the apical flagellomer of all but two species, and its shape and size appear to be useful for separating Philanthini from Cercerini within the subfamily. A total of eight types of sensilla (sensilla placoidea, sensilla basiconica, two types of pit organs, sensilla coelocapitula and three types of sensilla trichoidea) were found in all species, and an additional rarer type (grooved peg sensilla) was found only in three bee-hunting species and for first time in the genus Cerceris. Certain morphological features confirmed the separation of the apoid wasps from the rest of the Apoidea (i.e., bees). A cluster analysis based on the sizes of the different types of sensilla suggested that, overall, sensilla morphology is not a useful taxonomic tool, and thus, other factors likely determine interspecific variability. One candidate factor is the prey type, given some differences in the presence, density, size and distribution of certain types of olfactory sensilla between beetle-hunters and bee-hunters. This hypothesis needs to be further tested quantitatively using a larger species set, more individuals per species, additional sensilla features, and a correction for phylogeny.

(c) 2012 Académie des sciences. Published by Elsevier Masson SAS. All rights reserved.
\end{abstract}

\section{Introduction}

The antennae of insects play an important role in food selection, oviposition site selection, and intra- and interspecific communication [1-4]. This sensory capacity of the antennae is achieved through the antennal sensilla, which are the most important receptor organs. Among the Hymenoptera (bees, wasps and ants), these sensilla show

\footnotetext{
* Corresponding author.

E-mail address: cpolidori@mncn.csic.es (C. Polidori).
}

considerable diversity in terms of their morphology, density, and function (olfactory, gustatory, $\mathrm{CO}_{2}$ sensing, hygrothermal and tactile) [5-7].

There is important variability in the incidence, density, and distribution of different types of sensilla not only among species but also, to different extents, between sexes within a species [8-10]. In addition to phylogenetic effects on such variability, the morphology, numbers and distribution patterns of sensilla may be the product of interacting selection pressures related to feeding and foraging habits, habitats, mating systems, and sociality [11-16]. 
Within the Hymenoptera, very few studies have been performed on the comparative morphology of the antennal sensilla in Apoidea, and most of these have concerned bees (s.s, i.e., pollen-foraging Apoidea) $[8,15,17-19]$. This broad group also includes one large family of wasps, the Crabronidae, which have been the focus of a great number of behavioural and ecological studies in the last 100 years [20-22]. However, the diversity and morphology of the antennal sensilla have been investigated in detail in only five species in this family thus far [23,24], though ultrastructural features of a few olfactory sensilla types have been published for 10 additional species $[25,26]$. Briefly, the antennae of Crabronidae bear at least eight types of sensilla on their flagellomers, being particularly abundant on the more distal flagellomers, whose general morphology does not differ greatly from that found in bees, i.e., their closest relatives within the Aculeata [21]. In all species, olfactory sensilla, such as the sensilla placoidea and large sensilla basiconica, pit organs (potentially including $\mathrm{CO}_{2}$ and hygrothermal receptors), and threefour types of sensilla trichoidea (possibly with a gustatory or tactile function) are the most abundant. Their density and distribution appear to differ to some extent both among species and between sexes [23,24]. However, the available data on sensilla morphology are scattered among subfamilies of Crabronidae, so we still do not know the extent of the variability between closely related species (within subfamilies, tribes and genera), particularly when these species differ in terms of important behavioural and ecological traits, such as prey selection.

In fact, one of the main characteristics of apoid wasps is their relatively high specialisation regarding prey use at the species and often at genus level. A given species of wasp hunts only for a restricted group of prey species (rarely only one) belonging to a single order (and often to a single family) of insects or spiders [21]. In some cases, entire crabronid subfamilies are composed of species hunting for the same insect order, while in other subfamilies, different genera hunt for prey belonging to different orders [20,21].

From this point of view, the digger wasp subfamily Philanthinae appears to be an adequate group in which to carry out comparative morphological analyses, as it includes species hunting exclusively either for adult beetles or adult bees to feed their larvae, and this resource-use diversity is even retained within one genus (Cerceris) [27].

The aim of this study is to provide an inventory of the antennal sensilla of 10 species of philanthine wasps spanning three genera: Cerceris (including both beehunters and beetle-hunters), Philanthus (all bee-hunters) and Trachypus (all bee-hunters). The genera Philanthus and Trachypus are more closely related (tribe Philanthini) and are believed to be phylogenetically more primitive, while the genus Cerceris is considered more derived (tribe Cercerini) [28]. Hymenoptera are believed to represent the basal prey for this subfamily and, in turn, most likely for the genus Cerceris [27]. To date, the antennal sensillar equipment of philanthine wasps has been studied in detail in only two species (Cerceris rybiensis L. and Philanthus triangulum F.) $[23,24]$, both of which are bee-hunting species. We compared the external morphology of the antennal sensilla of eight additional species (and reanalysed $C$. rybiensis and $P$. triangulum), further searching for potential differences between beetle-hunters and beehunters.

\section{Materials and methods}

\subsection{Study organisms and examined material}

The subfamily Philanthinae (Hymenoptera: Crabronidae) is one of the richest taxa (including approximately 1140 species worldwide, distributed in eight genera) among the so-called digger wasps [29]. These species are solitary or primitively social predatory Hymenoptera that nest in the ground, digging multi-chambered nests where prey are placed and eggs are laid [21]. The developing offspring feed upon such prey, while adult wasps are nectar feeders on flowers [21,22].

For the present study, we selected females of 10 species: two from the genus Philanthus, one from the genus Trachypus and seven from the genus Cerceris (two beehunters and five beetle-hunters) (Table 1). Specialisation in terms of prey use varies among these species, ranging from the species-specific hunter $P$. triangulum and the family-specific hunters $C$. arenaria and $C$. bupresticida to more generalist species hunting for three or more families, such as C. rubida, P. pulchellus and T. denticollis (Table 1). All of the species analysed are solitary, with the exception of

Table 1

List of studied wasp species, with associated head width, prey, references for prey records and origin of samples.

\begin{tabular}{|c|c|c|c|c|}
\hline Species & $\begin{array}{l}\text { Head width } \\
(\mathrm{mm})(n=2)\end{array}$ & Prey & $\begin{array}{l}\text { References } \\
\text { for prey }\end{array}$ & Sample \\
\hline Cerceris arenaria (L.) & $3.5 \pm 0.1$ & Coleoptera (Curculionidae) & [45] & Field (Italy) \\
\hline Cerceris bupresticida Dufour & $3.4 \pm 0.2$ & Coleoptera (Buprestidae) & [54] & MNCN \\
\hline Cerceris quinquefasciata (Rossi) & $2.7 \pm 0.1$ & Coleoptera (Curculionidae, Chrysomelidae) & [55] & Field (Italy) \\
\hline Cerceris rubida (Jurine) & $2 \pm 0.1$ & $\begin{array}{l}\text { Coleoptera (Chrysomelidae, Curculionidae, Nitidulidae, } \\
\text { Phalacridae, Bruchidae, Scolytidae) }\end{array}$ & {$[46]$} & Field (Italy) \\
\hline Cerceris rybyensis (L.) & $2.8 \pm 0$ & Hymenoptera (Halictidae, Apidae, Andrenidae) & {$[55]$} & MNCN \\
\hline Cerceris sabulosa (Panzer) & $2.8 \pm 0.2$ & Hymenoptera (Halictidae, Apidae, Andrenidae, Colletidae) & [55] & Field (Germany) \\
\hline Cerceris tuberculata (Villers) & $5 \pm 0.1$ & Coleoptera (Curculionidae) & [55] & MNCN \\
\hline Philanthus pulchellus Spinola & $2.7 \pm 0.1$ & Hymenoptera (Halictidae, Apidae, Crabronide) & [56] & Field (Spain) \\
\hline Philanthus triangulum Fabr. & $3.4 \pm 0.2$ & Hymenoptera (Apidae: Apis mellifera) & {$[20]$} & Field (Italy) \\
\hline Trachypus denticollis Spinola & $4 \pm 0.2$ & Hymenoptera (Halictidae, Apidae, Colletidae, Crabronide) & [57] & Field (Chile) \\
\hline
\end{tabular}


C. rubida, which is one of the rare cases of social Philanthinae worldwide and the only case reported for Europe [30].

The examined material comes either from individuals collected in the field (preserved in 95\% ethanol) from a variety of European localities in recent years (2005-2010), or from pinned specimens from the entomology collection at the Museo Nacional de Ciencias Naturales (MNCN) in Madrid (Spain). Antennae of ethanol-preserved individuals were dried and then mounted on conventional microscopy stubs in either a dorsal, ventral or lateral orientation, then gold-coated. Whole pinned individuals from the museum collection were subjected to scanning electron microscopy without further preparation. Both the right and left antennae of two females per species were analysed.

\subsection{Scanning electron microscopy (SEM)}

SEM images were obtained using a ESEM QUANTA 200 microscope from the FEI Company (Oregon, USA) located at MNCN. We operated with three levels of vacuum (high vacuum and low vacuum 0.08 to 0.60 torr and environmental 1 to 20 torr). The low-vacuum mode (resolution: $3.0 \mathrm{~nm}$ at $30 \mathrm{kV}$ [SE], $4.0 \mathrm{~nm}$ at $30 \mathrm{kV}$ [BSE], and $<12 \mathrm{~nm}$ at $3 \mathrm{kV}$ [SE]) allows inspection at a high resolution and supports the analysis of non-conductive hydrated samples in their original condition with both the large field detector (LFD), as it is close to the sample and will avoid loss of electrons, and the backscatter detector (BSED, backscatter electron detector). This method was used for the specimens obtained from the museum collection. High vacuum conditions (resolution: $3.0 \mathrm{~nm}$ at $30 \mathrm{kV}$ [SE], $10 \mathrm{~nm}$ at $3 \mathrm{kV}$ [SE], and $4.0 \mathrm{~nm}$ at $30 \mathrm{kV}$ [BSE]) were used for the field samples covered with sputtered gold, providing a better resolution in the obtained electronic images. The accelerating voltage was $26 \mathrm{kV}$; the high and low vacuum were $0.40-0.50$ torr; and the working distance was $10 \mathrm{~mm}$.

\subsection{Sensilla classification and morphometric data}

For the inventory of the sensilla, we primarily followed the sensillar classification of Esslen and Kaissling [31] and Ågren [17], based on morphological characters. This classification should be considered as preliminary because the internal structure and the function of the different types of sensilla are still not fully known [5]. The flagellomeres were designated $\mathrm{Fl}^{1}$ to $\mathrm{Fl}^{10}$ in a proximal to distal direction.

Based on the SEM images taken of each entire antennal flagellomer, we qualitatively studied the distribution of sensilla types. We did not attempt to quantify the total number of sensilla because in some cases, it was difficult to photograph all flagellomeres in a perfect dorsal, ventral or lateral view for each species (due to the often twisted and bent shape of the antennae). However, for the sensilla placoidea, the most abundant olfactory organs (see also Results), we estimated the density [23]. We counted all of the sensilla placoidea within a square of $100 \mu \mathrm{m} \times 100 \mu \mathrm{m}$ situated approximately in the central zone of the dorsal side of $\mathrm{Fl}^{9}$ (a single measurement was performed on two antennae per species).

From pictures taken at higher magnifications (up to $3000 \times$ ), we calculated the size of the sensilla as follows. We superposed transparent sheets onto printed images showing the sensilla placoidea (SP), sensilla basiconica (SB), pit organs (PO), and sensilla coelocapitula (SC) from above (so that the bases/pits were easily visible), and a manual drawing of the pits where the pore plates lay (SP), the peg base (SB) or the pit (PO) was produced. Using pictures where the $S B$, sensilla trichoidea (ST: type $A, B$ and C/D) and grooved peg sensilla (GPS) were clearly visible laterally (i.e., the peg length was readily appreciable), we measured their length. Once all of the images were completed, we scanned and imported them into Image software (National Institutes of Health, USA), in which the lengths and areas (for pits and peg bases) of the investigated structures were calculated. The sample of sensilla used for size calculations came from one or both antennae from each species, depending on their visibility/ definition in the SEM images. Setae were not considered in the present work because although they are very abundant, these structures are non-innervated and have no known sensory role [32].

Finally, images obtained at higher magnifications (up to $10,000 \times$ ) were used to further analyse the morphology of the various sensilla types or particular areas of the flagellomeres qualitatively.

As a measure of wasp body size, we recorded the head width [33] (in two females per species), which has been shown to be positively correlated with antennae length in Hymenoptera [15].

\subsection{Statistical analysis}

For each type of sensilla, we calculated the minimum, maximum, means and standard deviation of the mean (SD) for lengths and/or areas (and density for SP). The small numbers of analysed individuals and, consequently, the lack of information regarding intraspecific variability did not permit any analysis of variance to be performed for interspecific comparisons. Instead, to preliminarily explore the relationships among species based on sensilla size, we carried out a hierarchical cluster analysis, which finds relatively homogeneous clusters of cases based on measured variables. The variables used for each species were the mean measures for all types of sensilla, except those for which the sample size (number of measurements taken) was small ( $n<10$ per species) (a total of eight variables were used). The cluster analysis was performed using Ward's method based on Euclidean distances (dissimilarity) between pairs of objects; this analysis also reported the dissimilarity value (truncation), which likely determines how many clusters best suit the data.

In the text and tables, mean values are shown \pm stanstandard deviation. To better demonstrate possible differences in sensilla size and density between beetle-hunters and bee-hunters, we also presented the data grouped by prey type (i.e., averaging the values of the single species and then calculating the means and SD across these 5 points [species] per category). 


\section{Results}

The head width ranged from 2 to $5 \mathrm{~mm}$ on average among the investigated species (Table 1).

The antennae of all of the species are typically filiform. They include a long scape at the proximal end, a rounded pedicel, and a flagellum (composed of 10 flagellomeres in female Apoidea) (Fig. 1). The $\mathrm{Fl}^{1}$ is longer than all of the other flagellomeres in all species.

In all species except for two ( $C$. rubida and C. bupresticida) (Fig. 2A), there is a small to conspicuous smooth area almost free of, or with very few, sensilla or setae on the tip of $\mathrm{Fl}^{10}$ (Fig. 2B-F). In C. quinquefasciata, this area is small and shield-shaped and is located on the tip (Fig. 2B). The same shape and position were recorded for C. tuberculata, but the size was much larger (almost covering the entire tip). In C. sabulosa, this area is also on the tip and is small and roughly circular (Fig. 2C). In C. arenaria, it is medium-sized and roughly oval and is also located on the tip (Fig. 2D). In C. rybyensis, the shape and position of the area resemble those in C. arenaria, but the oval is narrower and smaller. P. pulchellus and P. triangulum present a large and kidney-shaped area on the ventral side (larger in P. pulchellus) (Fig. 2E). Finally, the bare area in $T$. denticollis did not differ in its shape and position from that of Philanthus spp., although is slightly wider, making it the largest sensilla-free area recorded among the investigated species (Fig. 2F).

We recognised nine different types of sensilla, which are described in detail below.

\subsection{Pit organs (PO)}

These sensilla appear on the ventral and sometimes the lateroventral side of the 2nd to 10th flagellomeres (often forming fields) as cuticular openings, and they can include two types: the larger sensilla coeloconica (Scoel) and the smaller sensilla ampullecea (Samp) (Fig. 3A-B). In fact, despite Dietz and Humphreys [34] claiming the small pits

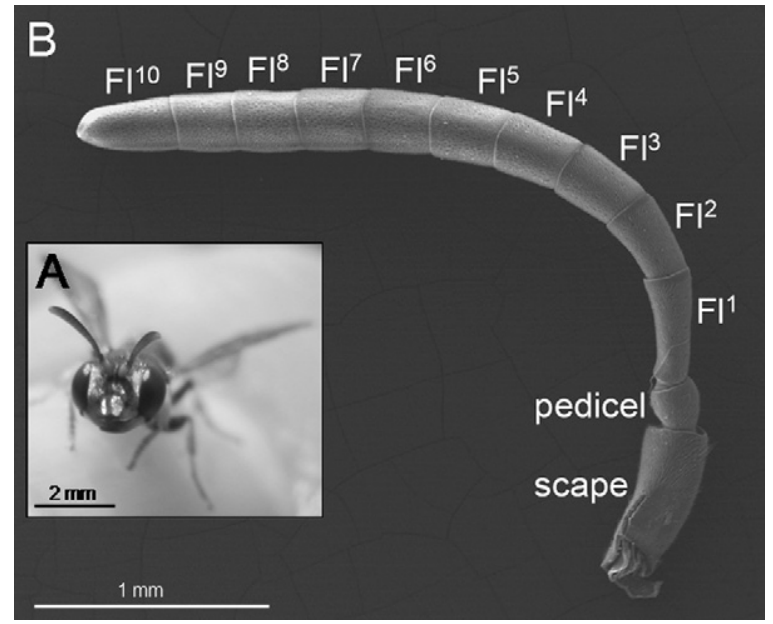

Fig. 1. A. A female philanthine wasp (C. rubida). B. Typical structure of the antenna in female Philanthinae (pictured: $C$. arenaria), composed of a scape, a pedicel and ten flagellomeres $(\mathrm{Fl})$. to be Samp and the wider ones to be Scoel in A. mellifera, the two types cannot be clearly differentiated based on external morphology using SEM; thus, we conservatively decided to suggest the presence of both only when differences in the area of the pit were clearly visible when the two types of sensilla were found close together (Fig. 3B). Among the investigated species, this difference was clear only in C. rybyensis, $C$. sabulosa and $C$. bypresticida (Fig. 3A and B). Thus, we preferred to group Samp and Scoel together as pit organs in the analysis of their distribution and size. The density of PO increases towards the tip of the antenna. The area of the PO pit ranged from 0.9 to $2.2 \mu \mathrm{m}^{2}$ across species (Table 2), and it averaged $1.5 \pm 0.6 \mu \mathrm{m}^{2}$ for beetle-hunters and $1.4 \pm 0.4 \mu \mathrm{m}^{2}$ for bee-hunters.

\subsection{Sensilla placoidea (SP)}

These olfactory discs or pore plates are oval/ellipticalshaped, and the pits where they lay have an area of $29.6 \pm 3.5 \mu \mathrm{m}^{2}$ (average among species) (Table 2), with the longitudinal axis being parallel to the longitudinal axis of the antenna (Fig. 3C). The distal end of the plate rises higher above the cuticle than the proximal end in all species (Fig. 3C-D), although in C. tuberculata and T. denticollis, this rise appears to be only slightly above the cuticle. A joint-like membrane connects the surrounding cuticle of the plate (Fig. 3D-E). The plate bears many pores. Pore plates are present in all flagellomeres but are rarer on $\mathrm{Fl}^{1}$ and much more abundant from $\mathrm{Fl}^{2}$ to $\mathrm{Fl}^{10}$, with abundance increasing from proximate to distal flagellomers. They are found, in particular, on the dorsal-lateral sides of flagellomeres (Fig. 4A), but they are also abundant ventrally. The area of the SP was $27.7 \pm 3.0 \mu \mathrm{m}^{2}$ in beetle-hunters and $31.6 \pm 2.3 \mu \mathrm{m}^{2}$ in bee-hunters.

The SP density at $\mathrm{Fl}^{9}$ ranged from 24 to 49 per species in the $100 \times 100 \mu \mathrm{m}^{2}$ observation squares (Table 2), and it appeared to be somewhat higher in beetle-hunters $(41.7 \pm 8.3$ vs. $27.5 \pm 2.5)$.

\subsection{Sensilla basiconica (SB)}

The sensilla basiconica are the largest sensilla, with a mean length of $8.8 \pm 1.8 \mu \mathrm{m}$ and a mean area of $65.5 \pm 25.2 \mu \mathrm{m}^{2}$ in the investigated species (Table 2 ). The surface of the large sensilla peg is sculptured longitudinally, with many thin furrows, and ends in a perforated tip (Fig. 3FI). The SB increase in number from the proximal to the distal end of the antenna and are present on the dorsal (and sometimes also the lateral) side (Fig. 4A-B) of the $\mathrm{Fl}^{2}-\mathrm{Fl}^{10}$ flagellomeres in all Cerceris spp., except $C$. sabulosa and C. rybyiensis, and from $\mathrm{Fl}^{3}$ to $\mathrm{Fl}^{10}$ in these two species and in Philanthus spp. and T. denticollis. Beetle-hunters seem to exhibit a larger SB area $\left(81.4 \pm 11.0 \mu \mathrm{m}^{2}\right)$ than bee-hunters $\left(49.6 \pm 22.7 \mu \mathrm{m}^{2}\right)$. Additionally, the length of the SB was $9.6 \pm 0.9 \mu \mathrm{m}$ for beetle-hunters and $7.9 \pm 1.9 \mu \mathrm{m}$ for beehunters.

When both the SB base area and SB length were considered together, some differences in the general shapes of the SB emerged. In particular, $C$. tuberculata appears to possess a fairly short, but large-based sensilla (length/area ratio: 0.46) (Fig. 3I), while P. pulchellus seems 


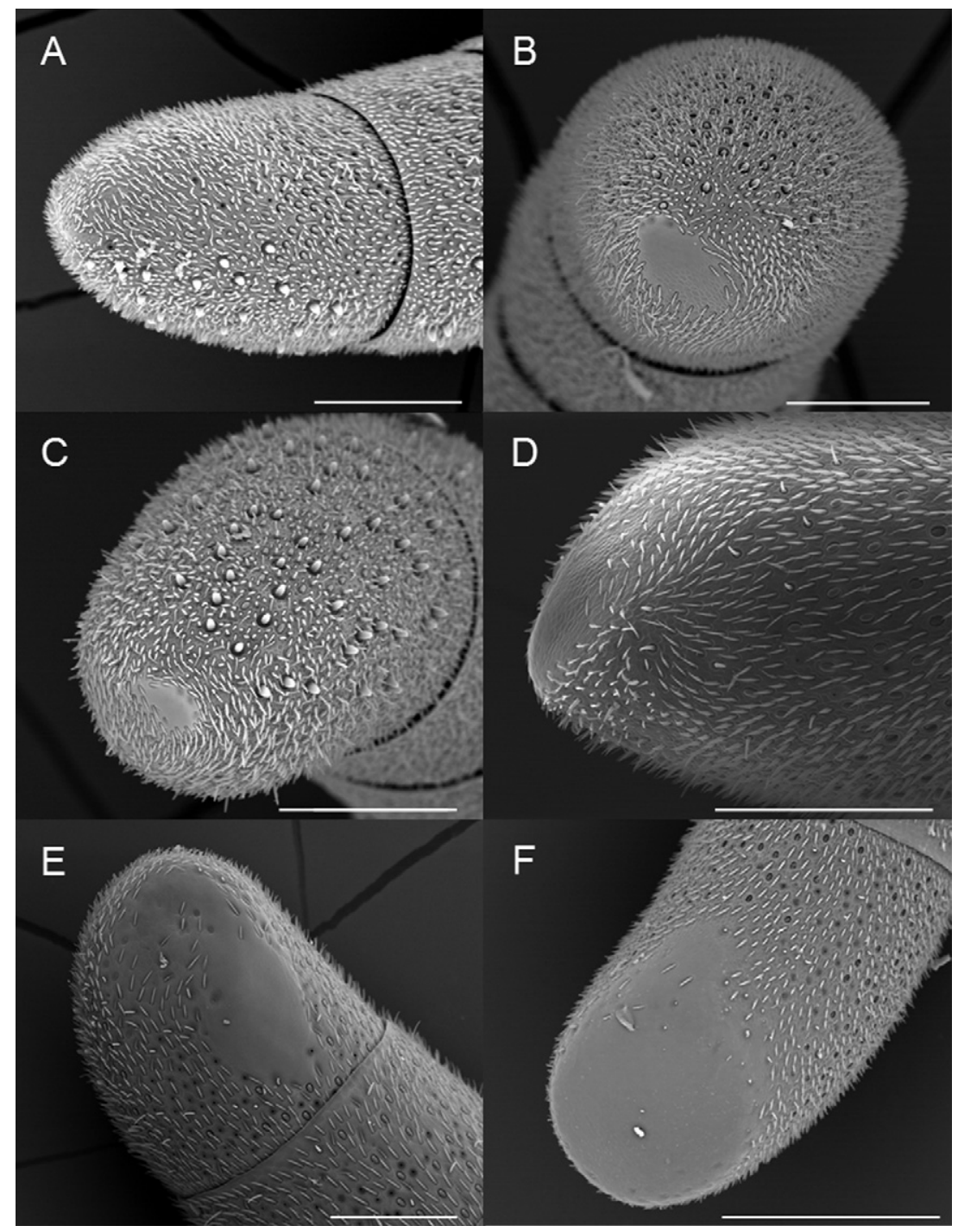

Fig. 2. Variability in the shape, position and size of the sensilla-free area on the apical portion of $\mathrm{F}^{10}$. A. C. rubida (absent). B. C. quinquefasciata (small and shield-shaped, tip). C. C. sabulosa (small and roughly circular, tip). D. C. arenaria (medium-sized and roughly oval, tip). E. P. pulchellus (large and kidneyshaped, ventral side). F. T. denticollis (large and kidney-shaped, ventral side). Bar indicates $100 \mu \mathrm{m}$ in all pictures except (F) in which it is $200 \mu \mathrm{m}$.

to possess a more elongated sensilla (length/area ratio: 0.54-0.57). The values for the other species appear to fall within these extremes (Fig. 3F-H).

\subsection{Sensilla trichoidea $A(S T-A)$}

This type of trichoid sensilla exhibits a smooth peg and a tuberculoid-like base connected to the surrounding cuticle through a joint-like membrane (Fig. 5A, C, D). ST-A were present on the dorsal or, more rarely, lateral side of the antennae from the 2nd to 10th flagellomer in Philanthus spp. and from the 1 st (very rare) to 10 th flagellomer in the other species. The highest density of STA was found at the apex of the antenna. The length of the ST-A was $12.8 \pm 4.8 \mu \mathrm{m}$ on average among the investigated species (Table 2); ST-A length was $15 \pm 0.4 \mu \mathrm{m}$ in beetlehunters and $10.4 \pm 5.6 \mu \mathrm{m}$ in bee-hunters.

\subsection{Sensilla trichoidea $B(S T-B)$}

These trichoid sensilla, which are slightly shorter than ST-A (11.2 $\pm 1.6 \mu \mathrm{m}$ average among all species, Table 2$)$, are sharp, thin and curved against the surface and exhibit longitudinal furrows (Fig. 5A). ST-B are found from $\mathrm{Fl}^{2}$ to $\mathrm{Fl}^{10}$ on the dorsal side and from $\mathrm{Fl}^{1}$ to $\mathrm{Fl}^{10}$ on the ventral side, with their number appearing to increase distally. The lengths of the ST-B was $10.8 \pm 2.1 \mu \mathrm{m}$ for beetle-hunters and $11.6 \pm 1.4 \mu \mathrm{m}$ for bee-hunters.

\subsection{Sensilla trichoidea $C / D(S T-C / D)$}

This group includes various sub-types of trichoid sensilla [23]. ST-C/D are characterised by longitudinal furrows and a wide socket (Fig. 5B) and are found on all flagellomeres both dorsally and ventrally. The length of ST- 


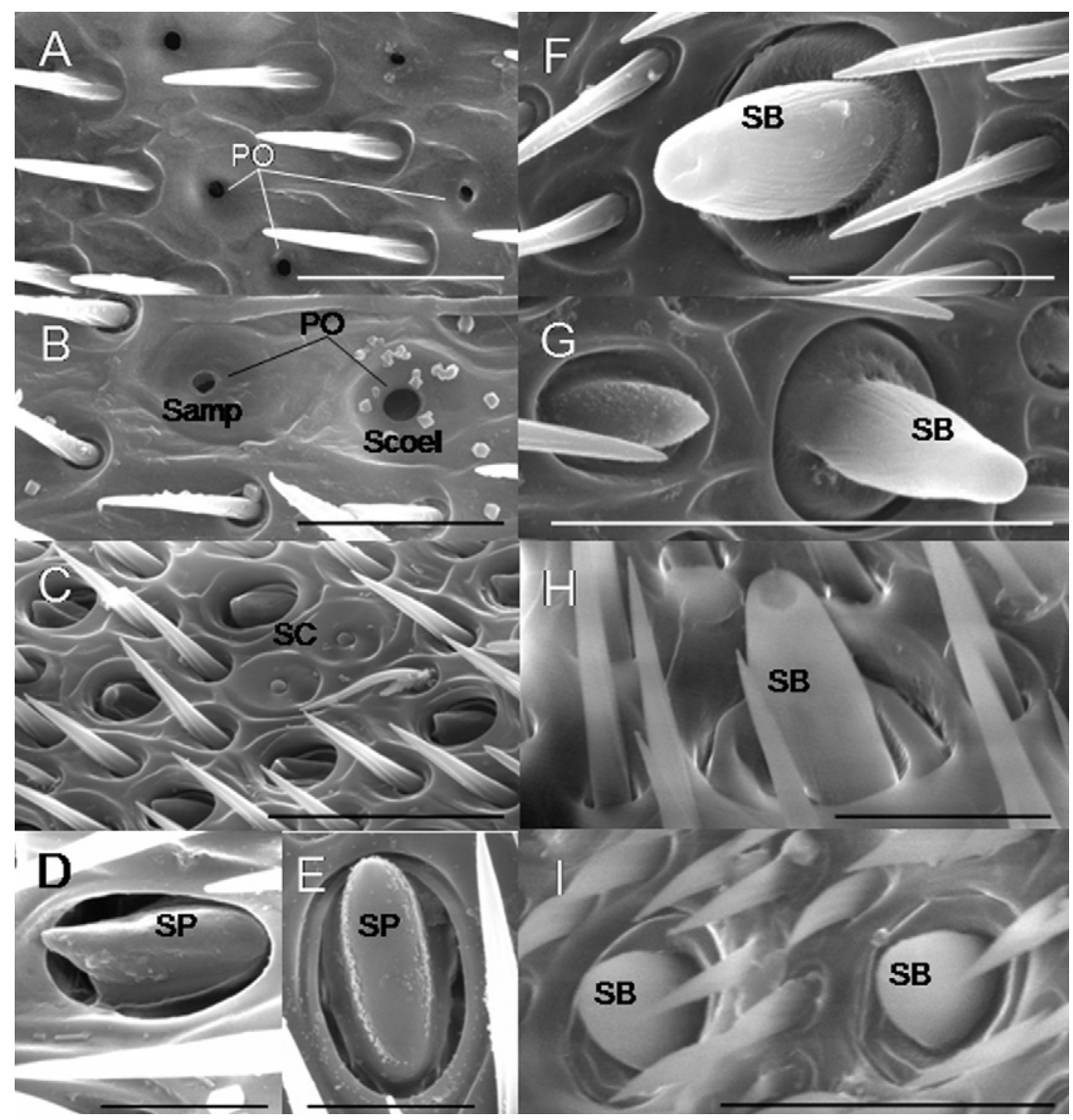

Fig. 3. Sensilla types on the flagella of philanthine wasps. A. P. triangulum (bar: $20 \mu \mathrm{m}$ ). B. C. sabulosa (bar: $10 \mu \mathrm{m}$ ). C. C. quinquefasciata (bar: $20 \mu \mathrm{m}$ ). D. C. arenaria (lateral view) (bar: $5 \mu \mathrm{m}$ ). E. C. rubida (dorsal view) (bar: $5 \mu \mathrm{m}$ ). F. C. rubida (bar: $10 \mu \mathrm{m}$ ). G. P. triangulum (bar: $20 \mu \mathrm{m}$ ). H. C. bupresticida (bar: $10 \mu \mathrm{m}$ ). I. C. tuberculata (bar: $20 \mu \mathrm{m}$ ). PO: pit organs; Samp: sensilla ampullecea; Scoel: sensilla coeloconica; SC: sensilla coelocapitula; SP: sensilla placoidea; SB: sensilla basiconica.

C/D was variable, being $10.4 \pm 3.2 \mu \mathrm{m}$ on average among all species (Table 2), and it appears to be similar in beetlehunters $(11.4 \pm 3.5 \mu \mathrm{m})$ and bee-hunters $(9.3 \pm 1.9 \mu \mathrm{m})$.

\subsection{Grooved peg sensilla (GPS)}

We found these peg-like organs only in P. triangulum, $P$. pulchellus and in $C$. sabulosa, whereas they were apparently lacking in all the other Cerceris spp. and in Trachypus. The base of the peg is sunk below the surrounding cuticular surface, and it contains deep longitudinal furrows (Fig. 5D). It was rarely observed on the dorsal side from $\mathrm{Fl}^{6}$ to $\mathrm{Fl}^{9}$. The length of the GPS was approximately $11 \mu \mathrm{m}$ on average in Philanthus spp. and approximately $6 \mu \mathrm{m}$ in C. sabulosa (Table 2 ).

\subsection{Sensilla coelocapitula (SC)}

This type of sensilla is characterised by a bulbous or button-like knob with an irregular surface emerging from an opening in the centre of a quite irregular oval concavity. SC are found ventrally and, notably, even in nearly bare areas where the other sensilla are types generally lacking (Fig. 3C and Fig. 6). For example, in some cases, they were found in close proximity to the sensilla-free area on the antennal apex (Fig. 6). SC were regularly observed to form compact clusters of 2-3 sensilla (Fig. 6C), and SC are often located in the vicinity of pit organs. Although SC are very rare compared to the other sensilla types, they were found scattered across all flagellomeres. The SC bulb area was $1.3 \pm 0.3 \mu \mathrm{m}^{2}$ on average among all investigated species (Table 2) and 0.9-1.2 $\mu \mathrm{m}^{2}$ for beetle-hunters and 1.3-1.9 for bee-hunters.

\subsection{Cluster analysis}

The dendrogram obtained through the cluster analysis indicated three main clusters (Fig. 7) (dissimilarity value of truncation $=0.93$ ). Cluster 1 (the first cluster shown from to the top down in the dendrogram) included two beetlehunters. Cluster 1 was closer to cluster 2 (distance between group centroid $=0.94$ ), which included two bee-hunters and three beetle-hunters, compared to cluster 3, which was the most dissimilar group from the others (distances to group 1 centroid = 1 and to group $2=1.43$ ), contained three bee-hunters. In the "mixed group" (cluster 2 ), the two bee-hunting species were not highly similar. These similarity patterns show that the sensilla morphology and 
Table 2

Mean area and/or length $( \pm \mathrm{SD})$ of the antennal sensilla in the studied species, and SP density on the $\mathrm{Fl}^{9}$.

\begin{tabular}{|c|c|c|c|c|c|c|c|c|c|c|}
\hline Variable & C. arenaria & C. bupresticida & C. quinquefasciata & C. rubida & C. rybyensis & C. sabulosa & C. tuberculata & P. pulchellus & P. triangulum & T. denticollis \\
\hline PO (area) $\left(\mu \mathrm{m}^{2}\right)$ & $\begin{array}{l}0.9 \pm 0.3 \\
(10)\end{array}$ & $\begin{array}{l}2.2 \pm 1.1 \\
(12)\end{array}$ & $\begin{array}{l}0.9 \pm 0.4 \\
(10)\end{array}$ & $\begin{array}{l}1.5 \pm 0.3 \\
(13)\end{array}$ & $\begin{array}{l}1.1 \pm 0.4 \\
(11)\end{array}$ & $\begin{array}{l}1.3 \pm 0.7 \\
(11)\end{array}$ & $\begin{array}{l}2.2 \pm 0.3 \\
(14)\end{array}$ & $\begin{array}{l}2.1 \pm 0.4 \\
(10)\end{array}$ & $\begin{array}{l}1.1 \pm 0.2 \\
(11)\end{array}$ & $\begin{array}{l}1.4 \pm 0.2 \\
(9)\end{array}$ \\
\hline $\mathrm{SP}$ (area) $\left(\mu \mathrm{m}^{2}\right)$ & $\begin{array}{l}28.8 \pm 1.5 \\
(18)\end{array}$ & $\begin{array}{l}32.6 \pm 3.2 \\
(37)\end{array}$ & $\begin{array}{l}28.1 \pm 3.9 \\
(18)\end{array}$ & $\begin{array}{l}23.8 \pm 0.6 \\
(18)\end{array}$ & $\begin{array}{l}29.7 \pm 1.5 \\
(18)\end{array}$ & $\begin{array}{l}27.9 \pm 1.2 \\
(24)\end{array}$ & $\begin{array}{l}25.2 \pm 2.0 \\
(40)\end{array}$ & $\begin{array}{l}33.2 \pm 3.9 \\
(24)\end{array}$ & $\begin{array}{l}33.5 \pm 3.3 \\
(18)\end{array}$ & $\begin{array}{l}33.7 \pm 3.8 \\
(18)\end{array}$ \\
\hline $\mathrm{SP}$ density at $\mathrm{Fl}^{9}$ & $\begin{array}{l}46 \pm 7 \\
(2)\end{array}$ & $\begin{array}{l}34 \pm 2 \\
(2)\end{array}$ & $\begin{array}{l}29.5 \pm 0.5 \\
(2)\end{array}$ & $\begin{array}{l}49.5 \pm 2.5 \\
(2)\end{array}$ & $\begin{array}{l}31.5 \pm 4.5 \\
(2)\end{array}$ & $\begin{array}{l}26.5 \pm 4.5 \\
(2)\end{array}$ & $\begin{array}{l}49.5 \pm 3.5 \\
(2)\end{array}$ & $\begin{array}{l}28 \pm 1 \\
(2)\end{array}$ & $\begin{array}{l}24 \pm 4 \\
(2)\end{array}$ & $\begin{array}{l}27.5 \pm 7.5 \\
(2)\end{array}$ \\
\hline SB (area) $\left(\mu \mathrm{m}^{2}\right)$ & $\begin{array}{l}79.3 \pm 6.4 \\
(10)\end{array}$ & $\begin{array}{l}86.4 \pm 4.2 \\
(8)\end{array}$ & $\begin{array}{l}78.0 \pm 7.4 \\
(16)\end{array}$ & $\begin{array}{l}64.8 \pm 4.6 \\
(11)\end{array}$ & $\begin{array}{l}18.8 \pm 2.6 \\
(15)\end{array}$ & $\begin{array}{l}73.3 \pm 10.8 \\
(11)\end{array}$ & $\begin{array}{l}98.6 \pm 12.3 \\
(8)\end{array}$ & $\begin{array}{l}43.6 \pm 3.4 \\
(20)\end{array}$ & $\begin{array}{l}78.1 \pm 10.5 \\
(9)\end{array}$ & $\begin{array}{l}34.4 \pm 3.0 \\
(7)\end{array}$ \\
\hline SB (length) $(\mu \mathrm{m})$ & $\begin{array}{l}8.8 \pm 1.2 \\
(9)\end{array}$ & $\begin{array}{l}11.0 \pm 0.7 \\
(8)\end{array}$ & $\begin{array}{l}9.9 \pm 0.4 \\
(8)\end{array}$ & $\begin{array}{l}10.1 \pm 0.9 \\
(8)\end{array}$ & $\begin{array}{l}4.9 \pm 0.9 \\
(11)\end{array}$ & $\begin{array}{l}8.3 \pm 0.8 \\
(8)\end{array}$ & $\begin{array}{l}8.5 \pm 0.8 \\
(8)\end{array}$ & $\begin{array}{l}8.8 \pm 0.9 \\
(8)\end{array}$ & $\begin{array}{l}10.7 \pm 0.6 \\
(8)\end{array}$ & $\begin{array}{l}6.9 \pm 0.8 \\
(8)\end{array}$ \\
\hline ST-A (length) ( $\mu \mathrm{m})$ & $\begin{array}{l}11.3 \pm 0.8 \\
(10)\end{array}$ & $\begin{array}{l}24.9 \pm 2.5 \\
(10)\end{array}$ & $\begin{array}{l}16.4 \pm 1.6 \\
(10)\end{array}$ & $\begin{array}{l}8.3 \pm 1.4 \\
(10)\end{array}$ & $\begin{array}{l}9.8 \pm 2.1 \\
(10)\end{array}$ & $\begin{array}{l}10.8 \pm 2.0 \\
(10)\end{array}$ & $\begin{array}{l}14.3 \pm 4.4 \\
(10)\end{array}$ & $\begin{array}{l}11.9 \pm 1.1 \\
(21)\end{array}$ & $\begin{array}{l}9.6 \pm 0.4 \\
(10)\end{array}$ & $\begin{array}{l}10.1 \pm 1.1 \\
(12)\end{array}$ \\
\hline ST-B (length) $(\mu \mathrm{m})$ & $\begin{array}{l}11.1 \pm 1.9 \\
(11)\end{array}$ & $\begin{array}{l}7.3 \pm 0.6 \\
(12)\end{array}$ & $\begin{array}{l}13.9 \pm 1.3 \\
(10)\end{array}$ & $\begin{array}{l}10.2 \pm 1.5 \\
(11)\end{array}$ & $\begin{array}{l}13.7 \pm 4.6 \\
(10)\end{array}$ & $\begin{array}{l}9.5 \pm 1.0 \\
(10)\end{array}$ & $\begin{array}{l}11.6 \pm 0.9 \\
(10)\end{array}$ & $\begin{array}{l}10.8 \pm 0.7 \\
(10)\end{array}$ & $\begin{array}{l}11.6 \pm 0.8 \\
(12)\end{array}$ & $\begin{array}{l}12.5 \pm 1.8 \\
(9)\end{array}$ \\
\hline ST-C/D (length) $(\mu \mathrm{m})$ & $\begin{array}{l}8.8 \pm 2.0 \\
(10)\end{array}$ & $\begin{array}{l}16.8 \pm 1.8 \\
(10)\end{array}$ & $\begin{array}{l}8.2 \pm 1.8 \\
(10)\end{array}$ & $\begin{array}{l}9.0 \pm 2.0 \\
(10)\end{array}$ & $\begin{array}{l}10.0 \pm 1.7 \\
(10)\end{array}$ & $\begin{array}{l}10.7 \pm 2.4 \\
(10)\end{array}$ & $\begin{array}{l}14.3 \pm 2.1 \\
(10)\end{array}$ & $\begin{array}{l}7.5 \pm 0.5 \\
(10)\end{array}$ & $\begin{array}{l}6.5 \pm 0.8 \\
(10)\end{array}$ & $\begin{array}{l}11.7 \pm 1.6 \\
(10)\end{array}$ \\
\hline GPS (length) $(\mu \mathrm{m})$ & - & - & - & - & - & $\begin{array}{l}6.2 \pm 1.0 \\
(2)\end{array}$ & - & $\begin{array}{l}11.2 \pm 1.5 \\
(3)\end{array}$ & $\begin{array}{l}10.9 \pm 1.9 \\
(3)\end{array}$ & - \\
\hline $\mathrm{SC}$ (area) $\left(\mu \mathrm{m}^{2}\right)$ & $\begin{array}{l}1.0 \pm 0.0 \\
(2)\end{array}$ & $\begin{array}{l}1.0 \pm 0.0 \\
(2)\end{array}$ & $\begin{array}{l}0.9 \pm 0.0 \\
(2)\end{array}$ & $\begin{array}{l}1.2 \pm 0.1 \\
(3)\end{array}$ & $\begin{array}{l}1.3 \pm 0.0 \\
(2)\end{array}$ & $\begin{array}{l}1.6 \pm 0.4 \\
(3)\end{array}$ & $\begin{array}{l}1.1 \pm 0.0 \\
(2)\end{array}$ & $\begin{array}{l}1.5 \pm 0.1 \\
(3)\end{array}$ & $\begin{array}{l}1.8 \pm 0.1 \\
(3)\end{array}$ & $\begin{array}{l}1.9 \pm 0.1 \\
(2)\end{array}$ \\
\hline
\end{tabular}

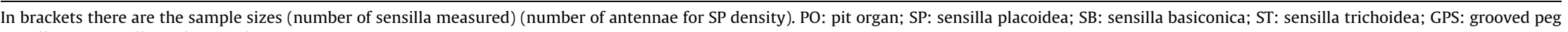
sensilla; SC: sensilla coelocapitula. 


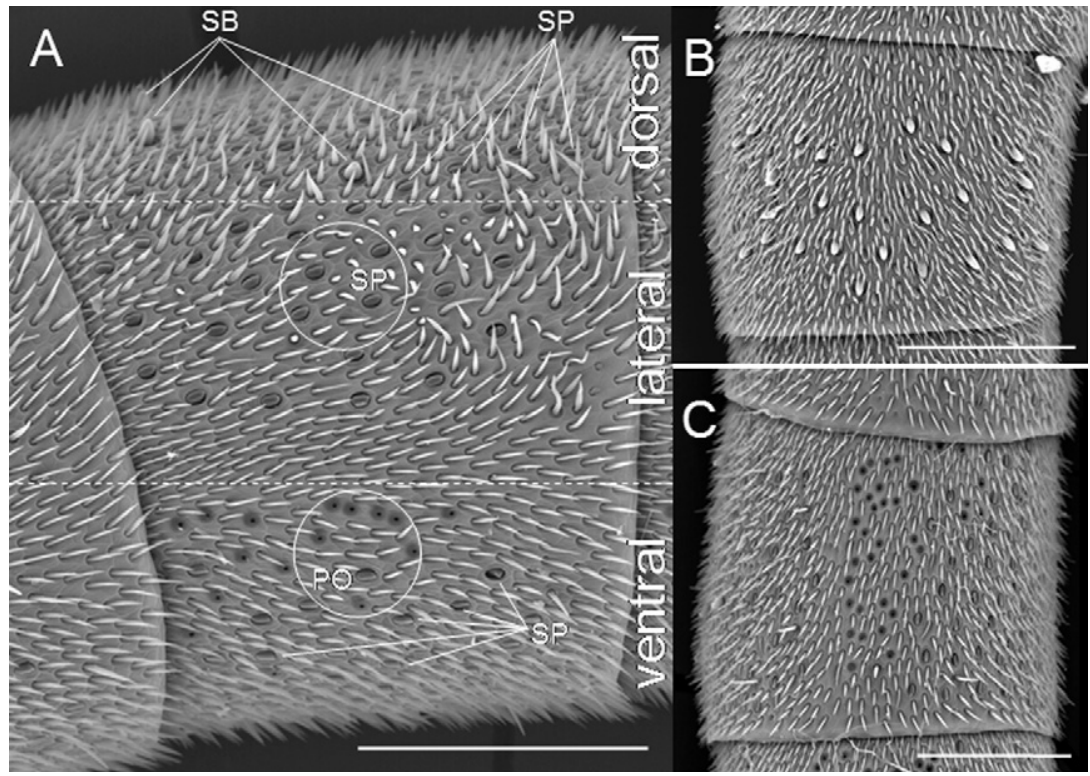

Fig. 4. Typical distribution of SP, SB and PO on a flagellomer. A. Inner lateral side of $\mathrm{Fl}^{7}$ in C. quinquefasciata. Note that SB are abundant on the dorsal side, $\mathrm{PO}$ on the ventral side, and SP on dorsal, ventral and lateral sides. B. Dorsal side of $\mathrm{Fl}^{9}$ in C. rubida with abundant SB. C. Ventral side of $\mathrm{Fl}^{8}$ of C. sabulosa with a field of PO. Bar is $100 \mu \mathrm{m}$.

density did not mirror the known taxonomic relationships among the studied species.

\section{Discussion}

This study contributes to current knowledge regarding the sensilla equipment in female apoid wasps, increasing the number of species studied in detail from five to 13 . Despite the fact that this study provides a very general view and the sensilla types were found to be morphologically similar across these 13 species and similar to other species of Apoidea (i.e., bees) [8,17,19,34,35], our results demonstrated some degree of variability in the size and, at least in one case (SB), the shape of different types of

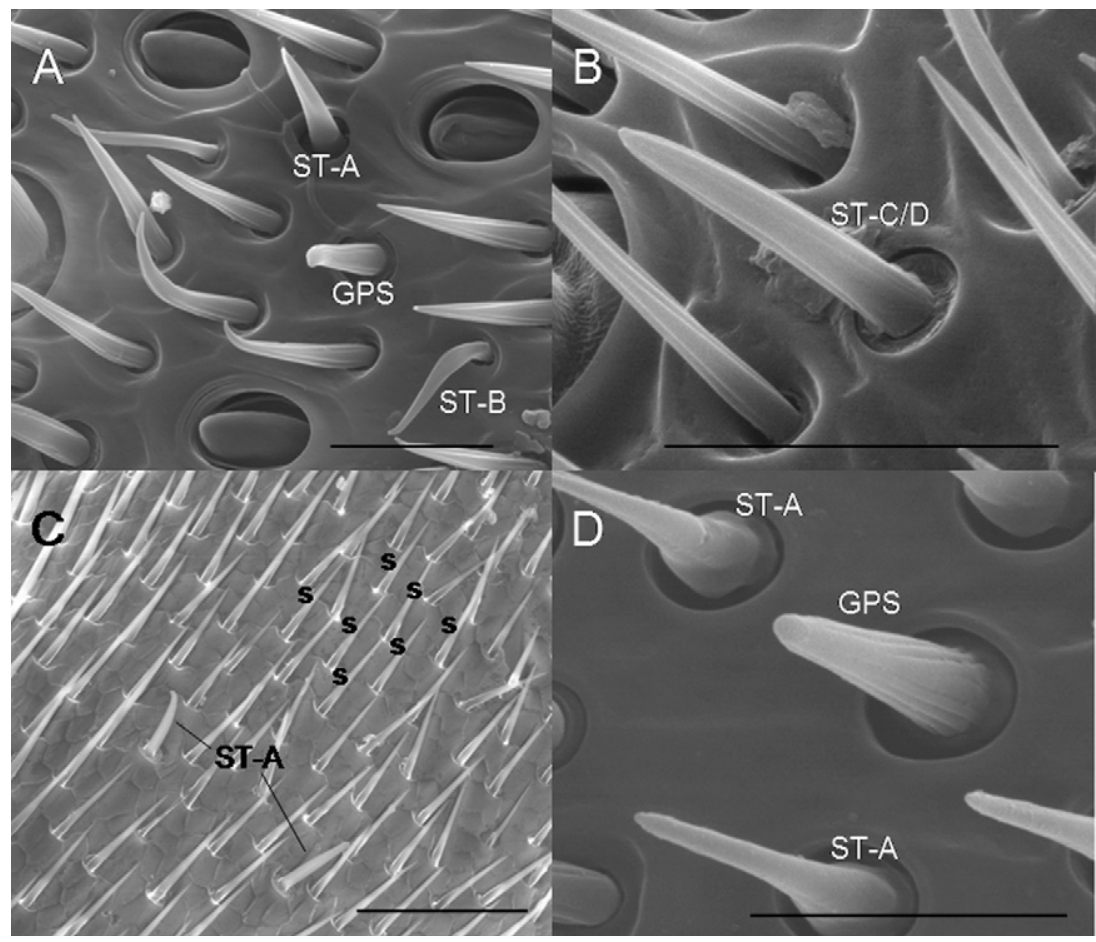

Fig. 5. Sensilla types on the flagella of philanthine wasps. A. C. sabulosa (bar: $10 \mu \mathrm{m}$ ). B. C. sabulosa (bar: $10 \mu \mathrm{m})$. C. P. coronatus (bar: $50 \mu \mathrm{m}$ ). D. P. pulchellus (bar: $20 \mu \mathrm{m}$ ). ST-A: sensilla trichoidea A; ST-B: sensilla trichoidea B; ST-C/D: sensilla trichoidea C/D; GPS: grooved peg sensilla; s: setae. 


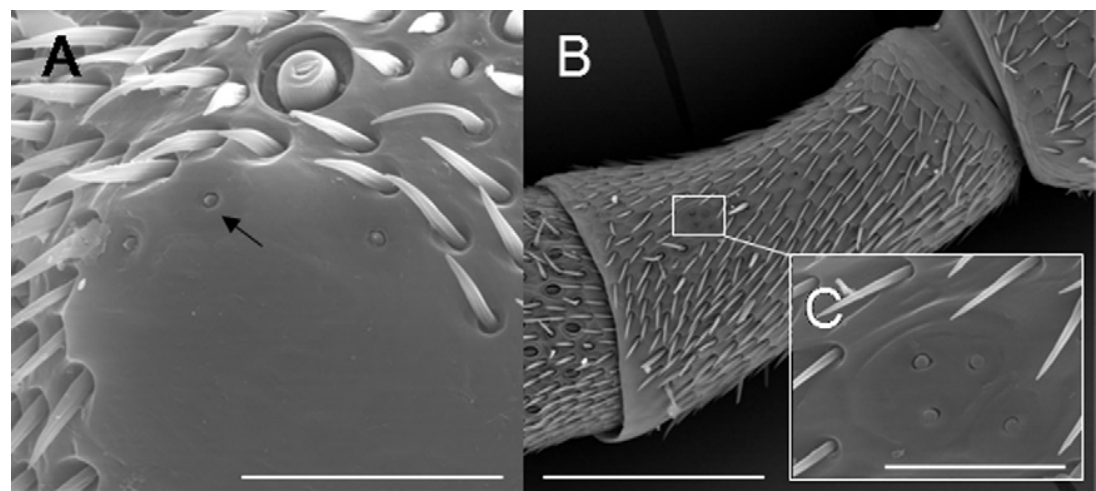

Fig. 6. Presence of SC (one is indicated by an arrow) in areas where all of the other types of sensilla were very rare or absent. A. Bare area at the apex of $\mathrm{F}^{10}$ in C. quinquefasciata (bar: $20 \mu \mathrm{m}$ ). B. Ventral side of $\mathrm{Fl}^{1}$ bearing SC in C. sabulosa (bar: $100 \mu \mathrm{m}$ ). C. Details of three fused and one separated SC (bar: $20 \mu \mathrm{m}$ ).

sensilla, even between closely related species (within genera of Philanthinae). Below, we discuss our findings from a comparative perspective using available information on females of other studied species of Apoidea (and in particular cases, also other types of insects) and previous observations on the two species of wasps investigated for the second time in this study ( $C$. rybyensis and $P$. triangulum). We conclude with a discussion regarding the possible effect of wasp ecology on their sensillar equipment.

\subsection{General patterns of sensilla distribution}

The general distribution patterns of the different sensilla types in the studied species do not differ markedly from those observed in other apoid wasps and in bees $[8,17,23,24,34,35]$. Most sensilla are mainly located dorsally and sometimes laterally and show increasing abundance distally. Two exceptions to this pattern are the PO, which appear to mainly aggregate in fields on the ventral side of flagellomeres (though in Bembix rostrata (L.), they are abundant on the lateral antennal surface [23]), and the SC, which were also found ventrally.

As in many bees and other studied apoid wasps [23,35], there is a bare, often ventral, zone on $\mathrm{Fl}^{10}$ in philanthine

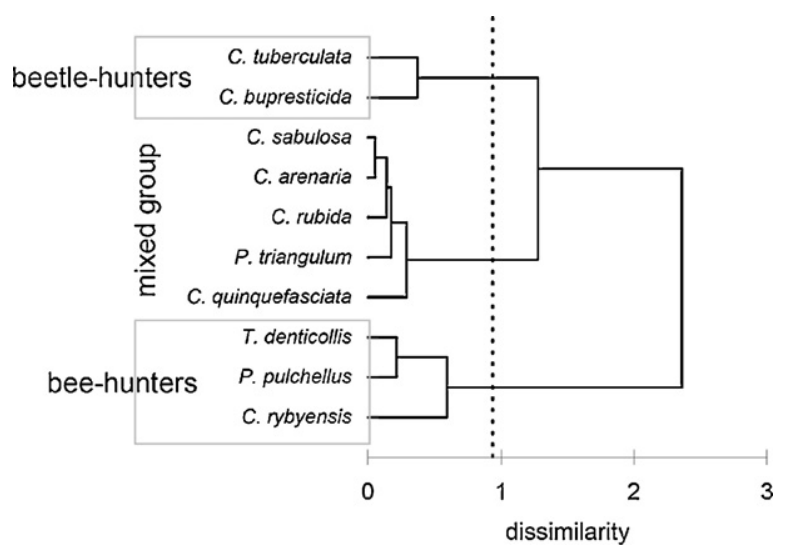

Fig. 7. Graphic representation of species dissimilarity based on agglomerative hierarchical clustering using measures of six types of sensilla (SP, SB, PO, ST-A, ST-B, ST-C/D). wasps. In this group, the shape and size of this sensilla-free area is highly variable: it is generally small and ovalcircular in most Cerceris species (and even lacking in two of these species), while it is quite large and kidney-shaped in Philanthus + Trachypus. Thus, it appears that the tribe Philanthini can be separated from the tribe Cercerini based on the presence, size and shape of this area on the antennal apex. However, in three apoid wasps of the subfamily Bembecinae (two species of Argogorytes and $B$. rostrata), there was also no sensilla-free area observed [23], while bees in the families Colletidadae, Andrenidae and Halictidae presented a sensilla-free area with an oval shape and a medium-to-large size $[8,17,35]$. Thus, discrimination of tribes based on the characteristics of this area could work within Philanthinae, but not within Crabronidae or Apoidea. The function of this sensilla-free area is not known.

\subsection{Morphology of the sensilla}

In general, all of the sensilla types observed in the 10 philanthine wasp species closely resemble those observed in other apoid wasps $[23,24]$ and have homologous counterparts in bees $[8,17,19,34,35]$.

The pit organs (PO) in the investigated species (and in apoid wasps in general) have a remarkably similar external morphology to those observed in bees $[8,17,35]$, with smaller and larger pores, which according to the study by Dietz and Humphreys [34] on Apis mellifera L., should correspond to sensilla ampullacea (Samp) and sensilla coeloconica (Scoel), respectively. However, as also observed in some bee and wasp species, distinction of these structures is difficult based solely on SEM analysis, and histological preparation of sensilla sections is necessary to ascertain which pores belong to each of the two types of pit organs. In Sphecodes bees and the halictid bee Augochlora pura (Say) [15], the distinction was more accurate because in Samp, no inner pit structure was detected by SEM, while in Scoel a low furrowed peg is often observed [35]. In Sphecodes, the pit areas were approximately $0.4 \mu \mathrm{m}^{2}$ for Samp and $3.6 \mu \mathrm{m}^{2}$ for Scoel [35], while in Bembecinae, the Scoel appeared to be much larger $\left(7-28 \mu \mathrm{m}^{2}\right.$, depending on the species) [23] (areas calculated from data on diameters). Among Bembecinae wasps, Ågren [23] 
assessed the presence or absence of Samp and Scoel based on the visibility of this peg. These structures were not as clear in the species studied here. Nevertheless, we were at least able to demonstrate that clear size dimorphism was observed in $C$. rybyensis, $C$. sabulosa and $C$. rubida through direct observations performed on closely situated pits. We cannot exclude the possibility that some species lack one of the two types of $\mathrm{PO}$, as this situation has been reported for other apoid wasps [23]. Samp act as $\mathrm{CO}_{2}$, temperature and/or humidity receptors in A. mellifera [36] and $\mathrm{CO}_{2}-$ receptors in ants [37]. Scoel are assumed to have similar functions in A. mellifera [38].

The sensilla placoidea (SP) in the studied species did not differ compared to other bees and wasps described previously in their general appearance (roughly circular or oval plates connected within the pit through a membrane). They are approximately $20-40 \mu \mathrm{m}^{2}$ in size, which does not differ considerably from the size observed in bembecine wasps $(6-8 \mu \mathrm{m}$ along the long axis, which would roughly correspond to an area of approximately 20$40 \mu \mathrm{m}^{2}$ for an oval shape with a short axis $=2 / 3 \times$ long axis) [23] but is markedly smaller than what is observed in some bees (Colletidae) (11-16 $\mu \mathrm{m}$ along the long axis, i.e., approximately $70-150 \mu \mathrm{m}^{2}$ for an oval shape with a short axis $=2 / 3 \times$ long axis) [17].

The SP in apoid wasps also show other visible morphological differences compared to bees. In fact, while in bees, the SP exhibit plates that are either level with, or slightly above, the surrounding cuticle $[8,17,19,31,35]$, in Bembecinae [23], Philanthinae $[23,24]$ (this study) and other apoid wasps [26], the SP are characterised by pore plates elevated from the surrounding cuticle (though weakly in C. tuberculata and $T$. denticollis). As SP are multiporous single-walled sensilla [26] that are known to respond to volatiles [11] (and references therein), these structures were assessed as olfactory organs in Apoidea.

The sensilla basiconica (SB) are large sensilla with a typical stout, cylindrical, bulbous morphology in apoid wasps [23-25] (this study). In contrast, bees exhibit typically slender, long SB with small sockets $[8,17,35]$. In addition, in this study, we demonstrated that the peg shape also shows variability within Philanthinae: some species present more elongated SB, while other SB exhibit a large base and a shorter peg. The sizes of the SB, in general, do not appear to be particularly dissimilar from the sizes in apoid wasps of other subfamilies (approximately 8-10 $\mu \mathrm{m}$ in length [23], compared to approximately 5-11 $\mu \mathrm{m}$ in the species studied here). The large SB were suggested to be olfactory or gustatory organs $[23,25,39]$.

The sensilla trichoidea A (ST-A) of philanthine wasps exhibit a very similar appearance to those of other apoid wasps [23] and bees [8,17,35]. These sensilla have been described as single-walled hairs with wall pores, suggesting that they most likely have an olfactory function [32].

The sensilla trichoidea B (ST-B) are just slightly smaller than the ST-A in Philanthinae (approximately $11 \mu \mathrm{m}$ vs. $13 \mu \mathrm{m}$ in the studied species); their length is similar to that observed in colletid bees (approximately 10-11 $\mu \mathrm{m}$ ) [17]. Following Lacher [36] and as discussed by Agren [17] in A. mellifera, ST-B may act as mechanoreceptors.
The sensilla trichoidea C/D (ST-C/D) of the philanthine wasps did not differ from those found in bembecine wasps [23] and presumably include a mixture of trichoid types that are not easily distinguishable, in particular, the ST-C and ST-D of bees $[8,17,34]$. ST-C/D include the longest trichoid sensilla in most Apoidea, but in general, their length is extremely variable, such that on average, they do not appear to be very dissimilar from the ST-A and SB (Argogorytes furgei (Shuckard): $22 \mu \mathrm{m}$, Andrena spp.: $15 \mu \mathrm{m}$, Sphecodes spp.: 13-30 $\mu \mathrm{m}$, P. triangulum: 8$16 \mu \mathrm{m})[8,23,24,35]$. The same large size variability was found in the philanthine wasps studied here (maximum length/minimum length ratio ranging from 1.2 to 2.3 across the 10 species). A mechanoreceptor-gustatory function has been suggested for ST-C/D [31,32,36].

Grooved peg sensilla (GPS) were first found in Apoidea in $P$. triangulum by Herzner et al. [24], and we now show that these structures are present in at least one other species of Philanthus, P. pulchellus, and in the genus Cerceris (C. sabulosa). They have not been found in any of the other studied species of apoid wasps to date [23,24,26] (this study). However, caution should be taken in claiming that GPS are absent because this type of sensilla is rare, and we could have missed certain areas, particularly in twisted and bent antennae, where they may have been present. The length of the peg was found to be similar in our $P$. triangulum sample, in $P$. pulchellus and in the $P$. triangulum sample analysed by Herzner et al. [24] (approximately $9-10 \mu \mathrm{m}$ ), though it was somewhat shorter in C. sabulosa. The GPS of philanthine wasps resemble those found in other non-Hymenoptera insects $[40,41]$, and because they are thought to be double-walledpore sensilla, they are believed to have an olfactory function [42].

Similar to other types of sensilla, such as ST-A, ST-B and PO, the morphology of the sensilla coelocapitula (SC) observed in this study did not deviate from that observed in bees and in other apoid wasps. The distribution of these structures is also similar across species, with SC often forming small and dispersed groups along the 10 flagellomeres, commonly on the most proximal annuli and also on the very tip of the antenna, i.e., where the other types of sensilla are normally almost absent [8,17,23,24,31,35]. Notably, SC appear to be lacking in females of several species of bees (Hylaeus communis Nylander) [17] and bembecinae wasps (A. furgei) [23], whereas they were always found in Philanthinae [24] (this study). SC are most likely mechanoreceptors [31].

\subsection{Conclusions and a hypothesis to be tested in the future}

Overall, the variability in the morphology, size and distribution of sensilla types found in this study confirms the hypothesis of Ågren [23] that antennal sensilla features are not valuable as taxonomic tools in apoid wasps. With the sole exception of the shape and size of the sensilla-free area on $\mathrm{Fl}^{10}$, which appears to separate Philanthini and Cercerini, none of the features of these structures appear to be valid for discrimination among species, genera or tribes. The cluster analysis based on sensilla sizes confirms this observation. A weak impact of taxonomic relationships in 
determining sensillar morphology is also observed in some parasitoid hymenopterans, in which gustatory sensilla are similar among species, even in those belonging to different families, suggesting the existence of ecological factors shaping the forms of these structures [43]. Furthermore, the species grouping obtained with the cluster analysis appears to be independent of species size differences. For example, the three species in the tribe Philanthini have SP virtually of the same size, which are larger compared to those of the largest species in the sample (the beetlehunter $C$. tuberculata); furthermore, $T$. denticollis, one of the largest species, had the second smallest SB.

Thus, it is reasonable to hypothesise that variability in sensillar equipment arose from different ecological demands in different apoid wasps. Here, we preliminary suggest one ecological factor, prey type, as potentially shaping this process because it is a main ecological/ behavioural trait differing within species of the studied group. In fact, other factors, such as nesting habits and mating strategies, seem to be largely conservative in the subfamily [20].

Given the observed results, despite their mainly qualitative output, it appears that if prey type has shaped the form of the sensillar equipment, it would presumably act on olfactory sensilla because the differences between beetle-hunters and bee-hunters appeared to be best appreciable regarding both the size and distribution of SB and the density of SP. In particular, the overall, though tentative, suggestion is that beetle-hunters may achieve an increased olfactory sensitivity through larger SB (approximately 1.7-fold larger than bee-hunters), a greater abundance of SB (which are present on nine flagellomeres, compared to eight in bee-hunters), and a higher SP density (approximately 1.6-fold denser than bee-hunters).

However, why would beetle-hunters require enhanced olfaction compared to bee-hunters?

The general behaviour of bee and beetle prey may suggest one possible hypothesis. Wasp species that hunt for flying prey species on flowers, such as bees, certainly rely on olfaction, but mainly after an initial discrimination of the prey's size and shape using vision [44]. In contrast, wasp species hunting for beetle prey, which are often cryptic, exhibit poor mobility and live hidden in vegetation $[45,46]$, would rely more strongly on olfaction while searching and localising prey, while visual recognition, if any, takes place once the prey is found. Thus, bee-hunters would essentially use visual and short-range chemical stimuli to find and recognise their prey, while in addition to these factors, beetle-hunters would also heavily rely on long-range chemical stimuli to find prey. Thus, successful foraging might require increased olfactory sensitivity in beetle-hunters, and larger pegs of SB could represent more efficient olfactory organs, similar to what has been observed in other insects. For example, the demand for extreme sensitivity in moth pheromone communication supported the evolution of long sensilla with a high efficiency in capturing odour molecules [47]. The distribution of SB also appears to cover more flagellomeres in beetle-hunters, but this result should be further confirmed because one bee-hunter ( $C$. rybyensis) was shown to have SB on eight flagellomeres in the present study and on nine flagellomeres previously [23], and thus, we cannot exclude important intraspecific variation.

A higher SP density was related to olfactory sensitivity in previous studies on bees. For example, sensory allometry is associated with foraging task preferences and resource exploitation in A. mellifera, with the number of SP being greater in pollen and water foragers, which are known to exhibit higher sensory sensitivity compared to nectar foragers [48]. Additionally, A. mellifera males have a greater number of SP than workers (7.36 times more), possibly conferring the high olfactory sensitivity necessary to find the queen during the mating flight [49].

In further agreement with this hypothesis, Galvani et al. [19] estimated that in bees of the tribe Emphorini (Apidae), $85-90 \%$ of sensilla in males correspond to olfactory receptors compared to $60-75 \%$ in females, whereas the number of contact receptors was greater in females. In sweat bees (Halictidae), parasitic females, which are potentially mainly dependent on longer-range olfactory cues, have fewer olfactory sensilla than non-parasitic females, which also use contact or short-range olfactory cues [15]. The antennae of females the parasitoid species Tamarixia radiata (Waterston) (Hymenoptera: Eulophidae) have a greater number of SP than male antennae, suggesting a possible function in the perception of hostrelated volatile cues [50].

The role of resource (host, prey or pollen) specialisation (in terms of niche width) in determining the density/ number of SP is still debated in Hymenoptera. For example, the generalist braconid parasitoids Cotesia glomerata (L.) and $C$. marginiventris (Cresson) exhibit less SP than their specialist relatives $C$. rubecula (Marshall) and Microplitis croceipes (Cresson) [51,52]. In contrast, across bee families, oligolectic species do not have more SP than generalist species [15]. In the present study, a role of prey niche width also seems improbable, as the most specialised species (P. triangulum) shows one of the lowest SP densities, while more generalist species, such as C. rubida and C. sabulosa, showed widely ranging SP densities.

A relationship between foraging ecology and sensillar equipment, as preliminarily proposed here for digger wasps, is also supported by previous studies on nonaculeate Hymenoptera and non-hymenopteran insects. For example, females of the mymarid parasitoids Anaphes victus (Huber) and $A$. listronoti (Huber), despite possessing very similar antennal sensillar equipment, show differences in the number of one type of sensilla (sensilla chaetica type 4), which is lower in the solitary vs. the gregarious species [10]. In six species of Triatominae (Heteroptera), the number and distribution of four sensilla types was found to vary according more to habitat type (e.g., palm trees vs. human houses) than to how species are taxonomically related, supporting the idea that the patterns of antennal sensilla are sensitive indicators of adaptive process in these insects [53].

In conclusion, the sensillar equipment of philanthine wasps is complex, including many types of sensilla, and no evidence of a link between interspecific variability and taxonomic relationships among species is supported; instead, a candidate factor to be considered while searching for the causes of the observed variability may 
be prey type. A larger species dataset, an increased number of individuals per species, and a statistical analysis of species differences incorporating a robust correction for phylogeny are needed to confirm this hypothesis.

\section{Disclosure of interest}

The authors declare that they have no conflicts of interest concerning this article.

\section{Acknowledgments}

Thanks are due to the Generalitat Valenciana (Spain) and the Maremma Regional Park for issuing the permits necessary to collect some of the specimens analysed. This research was supported by a fund from the SYNTHESYS Project (http://www.synthesys.info/), which is financed by the European Community Research Infrastructure Action under the FP7 "Capacities" Programme at the Museo Nacional de Ciencias Naturales (CSIC) (Madrid, Spain). Financial support was also provided in part by the research projects funded by the Ministry of Science and Innovation (subprogram BOS) CGL2009-10111 and CGL-2010-15786.

\section{References}

[1] A.A. Cossé, J.L. Todd, J.G. Millar, L.A. Martínez, T.C. Baker, Electroantennographic and coupled gas chromatographic-electroantennographic responses of the mediterranean fruit fly, Ceratitis capitata, to maleproduced volatiles and mango odor, J. Chem. Ecol. 21 (1995) 18231836.

[2] A.B. Attygalle, G.N. Jham, A. Svatos, R.T. Frighetto, F.A. Ferrara, E.F. Vilela, M.A. Uchoa-Fernandes, J. Meinwald, (3E,8Z,11Z)-3,8,11-tetradecatrienyl acetate, major sex pheromone component of the tomato pest Scrobipalpuloides absoluta (Lepidoptera: Gelechiidae), Bioorg. Med. Chem. 4 (1996) 305-314.

[3] I. Paulmier, A.G. Bagneres, C.M.M. Afonso, G. Dusticier, G. Riviere, J.L. Clement, Alkenes as a sexual pheromone in the alfalfa leaf-cutter bee Megachile rotundata, J. Chem. Ecol. 25 (1999) 471-490.

[4] F.P. Drijfhout, A.T. Groot, Close-range attraction in Lygocoris pabulinus (L.), J. Chem. Ecol. 27 (2001) 1133-1149.

[5] H. Altner, Insect sensillum specifity and structures: an approach to a new typology, in: L. Le Magnen, P. MacLeod (Eds.), Olfaction and taste VI, Information Retrieval, London, 1977, pp. 295-303.

[6] N. Isidoro, F. Bin, S. Colazza, S.B. Vinson, Morphology of antennal gustatory sensilla and glands in some parasitoid Hymenoptera with hypothesis on their role in sex and host recognition, J. Hym. Res. 5 (1996) 206-239.

[7] J.Y. Kim, W.S. Leal, Ultrastructure of pheromone-detecting sensillum placodeum of the Japanese beetle, Popillia japonica Newman (Coleoptera: Scarabaeidae), Arth. Struct. Dev. 29 (2000) 121-128.

[8] L. Ågren, Flagellar sensilla of two species of Andrena (Hymenoptera: Andrenidae), Int. J. Insect Morphol. Embryol. 7 (1978) 73-79.

[9] H. Jourdan, R. Barbier, J. Bernard, A. Ferran, Antennal sensilla and sexual dimorphism of the adult ladybird beetle Semiadalia undecimnotata Schn. (Coleoptera: Coccinellidae), Int. J. Insect Morphol. Embryol. 24 (1995) 307-322.

[10] J. van Baaren, G. Boivin, J. Le Lannic, J-P. Nenon, Comparison of antennal sensilla of Anaphes victus and A. listronoti (Hymenoptera, Mymaridae), egg parasitoids of Curculionidae, Zoomorphology 119 (1999) 1-8.

[11] J. Spaethe, A. Brockmann, C. Halbig, J. Tautz, Size determines antennal sensitivity and behavioral threshold to odors in bumblebee workers, Naturwissenschaften 94 (2007) 733-739.

[12] J.R. Walther, Antennal patterns of sensilla of the Hymenoptera complex character of phylogenetic reconstruction, Verh. Natwiss. Ver. Hambg. 26 (1993) 373-392.

[13] H.H. Basibuyuk, D.L.J. Quicke, Gross morphology of multiporous plate sensilla in the Hymenoptera (Insecta), Zool. Scr. 28 (1999) 51-67.

[14] R.F. Chapman, Chemoreception: the significance of receptor numbers, Adv. Insect Physiol. 16 (1982) 247-356.
[15] W.T. Wcislo, Sensilla numbers and antennal morphology of parasitic and non-parasitic bees (Hymenoptera: Apoidea), Int. J. Insect Morphol. Embryol. 24 (1995) 63-81.

[16] E. Merivee, M. Rahi, A. Luik, Antennal sensilla of the click beetle, Melanotus villosus (Geoffroy) (Coleoptera: Elateridae), Int. J. Insect Morphol. Embryol. 28 (1999) 41-51.

[17] L. Ågren, Flagellar sensilla of some Colletidae (Hymenoptera: Apoidea), Int. J. Insect Morphol. Embryol. 6 (1977) 137-146.

[18] A.A. Al Ghamdi, Scanning electron microscopic studies on antennal sensilla organs of adult honey bee workers in genus Apis (Hymenoptera: Apidae), Bull. Entomol. Soc. Egypt 83 (2006) 1-11.

[19] G.L. Galvani, A. González, A.H. Roig-Alsina, B.P. Settembrini, Distribution and morphometric studies of flagellar sensilla in Emphorin bees (Hymenoptera, Apoidea). Micron (2011) doi:10.1016/j.micron. 2011.12.003

[20] H.E. Evans, K.M ÓNeill, The natural history of North American Beewolves, Cornell University Press, Ithaca, 1988.

[21] K.M. O'Neill, Solitary Wasps: Natural History and Behavior, Comstock Publishing Associates, Ithaca and London, 2001.

[22] H.E. Evans, K.M O'Neill, The Sand Wasps: Natural History and Behaviour, Harvard University Press, Cambridge, 2007.

[23] L. Agren, Flagellar sensillum patterns in Nyssoninae and Philanthinae wasps (Hymenoptera, Sphecidae), Zool. Scr. 18 (1989) 527-535.

[24] G. Herzner, T. Schmitt, K.E. Linsenmair, E. Strohm, Flagellar sensilla in male and female European beewolves, Philanthus triangulum F. (Hymenoptera: Sphecidae), Entomol. Fenn. 14 (2003) 237-247.

[25] R. Martini, Fine structure and development of the large sensilla basiconica on the antennae of sphecid wasps, Tissue Cell Res. 18 (1986) $143-151$.

[26] R. Martini, Ultrastructure and development of single-walled sensilla placodea and basiconica on the antennae of the Sphecoidea (Hymenoptera: Aculeata), Int. J. Insect Morphol. Embryol. 15 (1986) 183-200

[27] F.W. Gess, Prey and nesting sites of some sympatric species of Cerceris (Hymenoptera: Sphecidae), with a review and discussion of the prey diversity of the genus, Ann. Cape Prov. Mus. Nat. Hist. 13 (1980) 85-93.

[28] B.A. Alexander, A cladistic analysis of the subfamily Philanthinae (Hymenoptera: Sphecidae), Syst. Entomol. 17 (1992) 91-108.

[29] W.J. Pulawski, http://research.calacademy.org/ent/catalog_sphecidae, (last accessed on 5 of November 2011).

[30] C. Polidori, M. Federici, C. Papadia, F. Andrietti, Nest sharing and provisioning activity of female of the digger wasp, Cerceris rubida (Hymenoptera: Crabronidae), It. J. Zool. 73 (2006) 55-65.

[31] J. Esslen, K.-E. Kaissling, Zahl und Verteilung antennaler Sensillen bei der Honigbiene (Apis mellifera L.), Zoomorphologie 83 (1976) 227-251.

[32] L. Ågren, E. Hallberg, Flagellar sensilla of bumble bee males (Hymenoptera, Apidae, Bombus), Apidologie 27 (1996) 433-444

[33] M. Ohl, K. Thiele, Estimating body size in apoid wasps: the significance of linear variables in a morphologically diverse taxon (Hymenoptera, Apoidea), Museum fur Naturkudeder Humbolt Universitat zu Berlin 83 (2007) 110-124

[34] A. Dietz, W. Humphreys, Scanning electron microscopic studies of antennal receptors of the worker honey bee including sensilla campaniformia, Ann. Entomol. Soc. Am. 64 (1971) 919-925.

[35] L. Ågren, B.G. Svensson, Flagellar Sensilla of Sphecodes Bees (Hymenoptera, Halictidae), Zool. Scr. 11 (1982) 45-54.

[36] V. Lacher, Elektrophysiologische, Untersuchungen an einzelnen Rezeptoren für Geruch, Kohlendioxid, Luftfeuchtigkeit und Temperatur auf den Antennen der Arbeitsbiene und der Drohne (Apis mellifica L.), Zeitschrift für Vergleichende Physiologie 48 (1964) 587-623.

[37] C. Kleineidam, R. Romani, J. Tautz, N. Isidoro, Ultrastructure and physiology of the $\mathrm{CO}_{2}$ sensitive sensillum ampullaceum in the leafcutting ant Atta sexdens, Arthr. Struct. Dev. 29 (2000) 43-55.

[38] F. Yokohari, The coelocapitular sensillum, an antennal hygro- and thermoreceptive sensillum of the honey bee, Apis mellifera L, Cell Tissue Res. 233 (1983) 355-365.

[39] W. Gnatzy, S. Anton, S. Thier, Prey specificity and prey recognition in the digger wasp Liris niger Fabr.: the importance of close range chemical cues, in: G.G. Gribakin, K. Wiese, A.V. Popov (Eds.), Sensory Systems and Communication in Arthropods, Birkhäuser Verlag, Basel, 1990, pp. 21 25.

[40] R.E. Harbach, J.R. Larsen, Fine structure of antennal sensilla of the adult mealworm beetle Tenebrio molitor (Coleoptera, Tenebrionidae), Int. J. Insect Morphol. Embryol. 6 (1977) 41-60.

[41] P.G. Guerenstein, P.M. Guerin, Olfactory and behavioral responses of the bloodsucking bug Triatoma infestans to odours of vertebrate hosts, J. Exp. Biol. 204 (2001) 585-597.

[42] T.A. Keil, Morphology and development of the peripheral olfactory organs, in: B.S. Hansson (Ed.), Insect Olfaction, Springer-Verlag, Berlin, 1999, pp. 5-47. 
[43] J. Van Baaren, G. Boivin, D. Bourdais, O. Roux, Antennal sensilla of hymenopteran parasitic wasps: variations linked to host exploitation behavior, in: A. Mendez Vilas, J. Diaz Alvarez (Eds.), Modern research and educational topics in microscopy, Elsevier, 2007, pp. 345-352.

[44] G. Herzner, T. Schmitt, K.E. Linsenmair, E. Strohm, Prey recognition by females of the European beewolf and its potential for a sensory trap, Anim. Behav. 70 (2005) 1411-1418.

[45] C. Polidori, R. Boesi, C. Pesarini, C. Papadia, S. Bevacqua, M. Federici, F. Andrietti, Temporal relationship between the prey spectrum and population structure of the weevil-hunting wasp Cerceris arenaria (Hymenoptera: Crabronidae), Zool. Stud. 46 (2007) 83-91.

[46] C. Polidori, M. Gobbi, L. Chatenaud, D. Santoro, O. Montani, F. Andrietti, Taxon-biased diet preference in the generalist beetle-hunting wasp Cerceris rubida provides insights on the evolution of prey specialization in apoid wasps, Biol. J. Linn. Soc. 99 (2010) 544-558.

[47] R.A. Steinbrecht, Structure and function of insect olfactory sensilla, in: Olfaction in mosquito-host interactions, Ciba Foundation Symposium 200, John Wiley \& Sons, Chichester, 1996, pp. 158-177.

[48] A.J. Riveros, W. Gronenberg, Sensory allometry, foraging task specialization and resource exploitation in honeybees, Behav. Ecol. Sociobiol. 64 (2010) 955-966.

[49] A.C. Stort, M.M. Moraes-Alves, Differences in the number of antennal sensory structures of males of three honey bee types, Rev. Bras. Biol. 59 (1999) 161-166.

[50] E.O. Onagbola, D.R. Boina, S.L. Herman, L.L. Stelinski, Antennal sensilla of Tamarixia radiata (Hymenoptera: Eulophidae), a parasitoid of
Diaphorina citri (Hemiptera: Psyllidae), Ann. Entomol. Soc. Am. 102 (2009) 523-531.

[51] M.A.K. Bleeker, H.M. Smid, A.C. Aelst, J.J.A. van Loon, L.E.M. Vet, Antennal sensilla of two parasitoid wasps: a comparative scanning electron microscopy study, Micros. Res. Tech. 63 (2004) 266-273.

[52] P. Das, K. Sharma, L. Chen, H.Y. Fadamiro, Abundance of antennal chemosensilla in two parasitoid wasps with different degree of host specificity, Microplitis croceipes and Cotesia marginiventris may explain sexual and species differences in their response to host-related volatiles, Microsc. Res. Tech. 74 (2011) 900-909.

[53] A.N. Carbajal de la Fuente, S. Catalá, Relationship between antennal sensilla pattern and habitat in six species of Triatominae, Mem. Inst. Oswaldo Cruz 97 (2002) 1121-1125.

[54] S. Hanot, Une méthode de chasse de Buprestes intéressante grâce à Cerceris bupresticida Dufour (Hymenoptera, Sphecidae), Lambillionea 101 (2001) 659-662.

[55] K. Tsuneki, The biology of East-Asiatic Cerceris (Hymenoptera: Sphecidae) with special reference to the peculiar social relationships and return to the nest in Cerceris hortivaga Kohl, Etzenia 9 (1965) 1-46.

[56] J.D. Asís, J. Tormos, S.F. Gayubo, Behavior of Philanthus pulchellus (Hymenoptera: Sphecidae) with a description of its mature larvae, Ann. Entomol. Soc. Am. 89 (1996) 452-458.

[57] C. Polidori, R. Boesi, L. Ruz, J. Montalva, F. Andrietti, Prey spectrum and predator-prey size relationships of the solitary wasp, Trachypus denticollis, in central Chile (Hymenoptera: Crabronidae), Stud. Neotrop. Fauna Environ. 44 (2009) 55-60. 